\title{
Foundations for STEM Success: Implementing National Best Practices in a Liberal Arts College Setting
}

\section{Prof. Mary G. Noonan, Merrimack College}

Mary Noonan is an Associate Professor of Computer Science and former Dean of the School of Science and Engineering. She is co-PI of the Foundations for Stem Success program funded by the National Science Foundation, Grant \# DUE-1217285. She teaches undergraduate Computer Science courses and has served in many administrative roles. She is currently involved in developing effective retention strategies for computer science and engineering students in the first two years. Her research interests include mobile and web technologies.

\section{Dr. Marc Veletzos, Merrimack College}

Dr. Cynthia Baker McGowan, Merrimack College

Ms. Maureen Walsh Sakakeeny PE P.E., Merrimack College

Ms. Sakakeeny is an experienced civil engineer and higher education administrator. Her engineering expertise spans transportation infrastructure design, construction management, environmental planning, and sustainability consulting. She supports the Dean of Science and Engineering with student recruitment and retention initiatives, including expansion of graduate programs, and first-year student advising and support. Ms. Sakakeeny is a member of a number of professional organizations, including the American Society of Civil Engineers (Boston Section) and the Society of Women Engineers (Fellow). 


\section{Foundations for STEM Success: Implementing National Best Practices in a Liberal Arts College Setting}

\section{Problem Statement}

The President's Council of Advisors on Science and Technology has indicated that the US Higher Education system needs to produce more graduates in STEM fields to maintain a competitive position in the global economy. Increasing retention in STEM fields has been identified as an efficient approach to achieve these objectives. The Foundation for STEM Success (FS2) program is a model for STEM student success that uses a student-centered approach to academic preparation and learning, and creates an integrated institutional network of supports that increases students' self-efficacy, sense of belonging to their major, and belief in the importance of their contributions to society. These are key factors that affect retention in STEM fields. The FS2 program is funded by the National Science Foundation (Grant \# DUE-1217285), focuses on engineering and computer science (CS) majors and is designed to improve retention and graduation rates.

\section{Broad Impacts}

The FS2 project elements have been piloted at large public institutions, and this project expands their application and assesses their effectiveness within a smaller Liberal Arts college setting. The project strengthens the infrastructure for providing services for pre-freshman and matriculated students by fostering collaborations between faculty and students and students and their peers. The project is expected to increase the number of engineering and CS graduates and accelerate their progress toward completing their degree and will make significant positive contributions to the STEM workforce and the new global economy. The results will provide a rich assessment of approaches to retention that can be applied to all STEM disciplines.

\section{Goals}

The primary goals of this five year project are to, increase first year retention to $80 \%$ by Year 3, increase second year retention to $71 \%$ by Year 3, and increase the five-year graduation rate to $65 \%$ by Year 5. To accomplish the project goals, the FS2 program is divided into four initiatives (1) a summer intensive program, (2) a revised gateway course for engineering and CS majors, (3) a peer and faculty mentor/tutoring program, and (4) affinity housing.

\section{Approach}

The FS2 program initiatives are aimed at first year students and support students' adjustment to the challenges and rigors of a high quality academic program and involve upper-class students and faculty from engineering and CS. The program initiatives contribute to students' academic preparation and self-efficacy, particularly in first year mathematics courses, sense of belonging to a major and social integration within an academic community, and belief that the targeted 
majors contribute to society. These are key factors that have been shown to affect retention in STEM fields.

\section{Initiative \#1: Summer Bridge Program}

Summer preparatory ("bridge”) programs have been demonstrated to effectively bridge the gap between high school and college through academic and enrichment activities, and these programs are effective for high-risk groups, such as first-generation students. ${ }^{1,2,3}$ In this program, students build relationships and network with other students, faculty, and staff. In addition, they become familiar and comfortable with the campus, academic expectations, and campus resources. Summer bridge programs have been shown to overcome the barriers that contribute to student attrition in STEM. These barriers include, misinformation about science curricula, lack of preparation for the academic challenges associated with a degree in the sciences, and the absence of a quality mentoring relationship with a faculty member early in the first year of courses. ${ }^{4}$

The Summer Bridge Program is a two-week initiative to improve the preparation of students for college-level studies, particularly first year mathematics. This program also includes career exposure through hands-on activities, seminars, and field trips. The target population for the summer bridge program is students with: low high school grades; low standardized math scores; low math placement (i.e. algebra or precalculus). Participation in the summer bridge program is often a requirement for admission to the college.

The Summer Bridge Program has two goal, (1) to improve student preparation and first-year mathematics placement through a mathematics review, and (2) to excite new students about their chosen majors through activities meant to create a sense of belonging and inform students about career options.

The two-week program consists of a series of seminars, field trips, workshops, and design competitions that expose students to the breadth of career opportunities available to them, as well as prepare them for their freshman year mathematics (see Figure 1). The first week schedule for the 2015 Summer Bridge Program is shown in Figure 2. The summer intensive program is taught by faculty from CS, civil, mechanical, and electrical engineering. Three upper division student mentors and a graduate student fellow provide additional support, mentoring and oversight of the students. The summer bridge participants live on-campus for the full program in the dorm room assigned to them for the fall semester, to ease their transition into college life. At the end of the Summer Bridge Program students retake the Math Placement Exam and have the opportunity to move up one math course if they show sufficient improvement. 

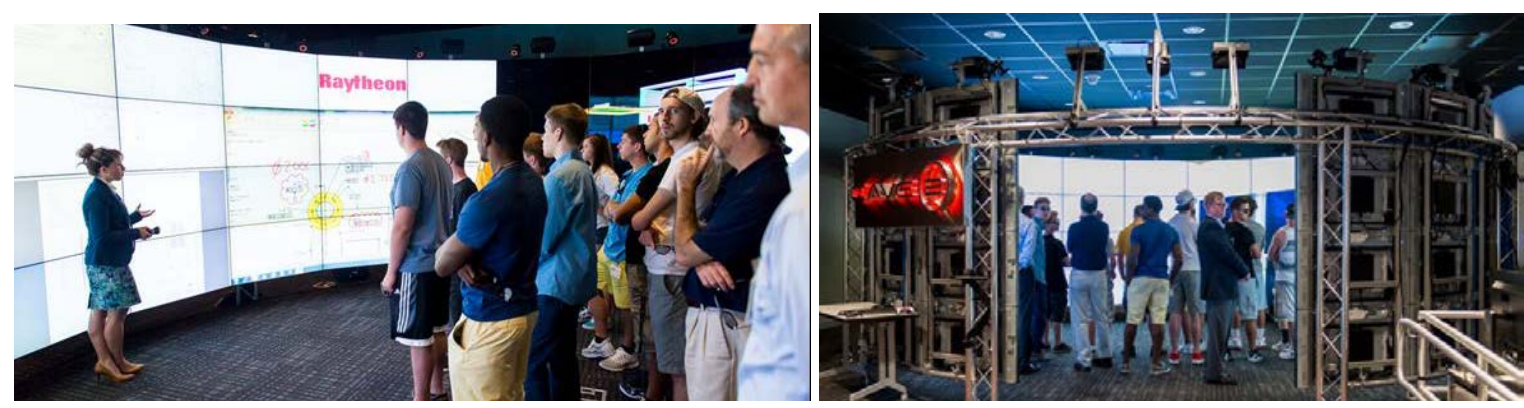

Figure 1 Sumer Bridge Students on a tour of Raytheon's "CAVE2" 3D visualization studio

\begin{tabular}{|c|c|c|c|c|c|}
\hline & Monday (8/17) & Tuesday $(8 / 18)$ & Wednesday (8/19) & Thursday $(8 / 20)$ & Friday $(8 / 21)$ \\
\hline 8:00 AM & Breakfast & Breakfast & Breakfast & Breakfast & Breakfast \\
\hline 9:00 AM & $\begin{array}{l}\text { Introduction to the } \\
\text { Program }\end{array}$ & Math Quiz and review & Math Quiz and review & Math Quiz and review & Math Quiz and review \\
\hline 10:30 AM & Break & Break & Break & Break & Break \\
\hline $10: 40 \mathrm{AM}$ & $\begin{array}{l}\text { Civil Engineering } \\
\text { Hands-On Activity }\end{array}$ & $\begin{array}{l}\text { Guest Speaker } \\
\text { (CJ Wong, } \\
\text { McQuade Library) } \\
\end{array}$ & Extended Math & $\begin{array}{l}\text { Mechanical Engineering } \\
\text { Hands-On Activity }\end{array}$ & Field Trip \\
\hline 12:00 PM & Lunch & Lunch & Lunch & Lunch & and Turner Construction \\
\hline 1:00 PM & CE Hands-On Activity & \multirow{4}{*}{$\begin{array}{l}\text { Field Trip } \\
\text { (Raytheon) }\end{array}$} & \multirow{3}{*}{$\begin{array}{l}\text { Field Trip } \\
\text { (iRobot) }\end{array}$} & ME Hands-On Activity & Site) \\
\hline 2:30 PM & Break & & & Break & \\
\hline 2:40 PM & CE Hands-On Activity & & & ME Hands-On Activity & \\
\hline 4:00 PM & Adjourn & & Adjourn & Adjourn & Adjourn \\
\hline 5:00 PM & Dinner & Dinner & Dinner & Dinner & Dinner \\
\hline 6:00 PM & Evening activity & Evening activity & Evening activity & Evening activity & Evening activity \\
\hline 7:00 PM & HW time & HW time & HW time & HW time & HW time \\
\hline 10:00 PM & Official lights out & Official lights out & Official lights out & Official lights out & Official lights out \\
\hline
\end{tabular}

Figure 2 Schedule for the First Week of the 2015 Summer Bridge Program

\section{Initiative \#2: Revised Gateway Course}

The Introduction to Engineering gateway course serves as a first-year experience for engineering students course is a required course for all incoming engineering students. The gateway course provides inspiration about the disciplines and a strong sense of belonging, develops communication skills, and provides improved academic preparation by introducing a more rigorous introduction to engineering mathematics. As part of the FS2 project the gateway course has been expanded to include CS majors and has been revised to include a collaborative teambuilding design project. This interdisciplinary design project offers first year engineering and CS students with valuable experience working in teams on a hands-on practical problem.

First-year experiences, in particular overview freshmen seminars that introduce and orient STEM students to college-level studies, are a best practice for enhancing skills in the sciences and engineering, strengthening peer learning, and improving retention. Students develop relationships with one another, faculty, and the community; a sense of personal responsibility for academic progress; and an appreciation for education culture, diversity, and tolerance. ${ }^{5,6}$ Studies have shown that participation in a first-year experience leads to improved academic performance throughout a student's college career. ${ }^{7,8,9}$ The retention benefits are also clear. Numerous 
studies have shown that first-year experiences allow students to forge tighter bonds with their classmates and create a community of learners that increases persistence and graduation rates. ${ }^{10}$ The retention effects of these experiences are most pronounced for high-need students, including Hispanics and first-generation students. ${ }^{11}$

The expanded Introduction to Engineering and Computer Science gateway course is team taught by faculty from civil and mechanical engineering, electrical engineering, and computer science. The course is structured as writing-intensive lectures, labs, and team-based projects. This lecture and lab are divided into sections according to their major and introduces students to the profession of engineering/CS and provides freshman students with the communication skills needed in college and throughout their careers. Students learn to use the tools of their major in their discipline specific labs, such as computer-aided design software or programming development platforms.

In addition to lecture and labs, students meet once per week for an interdisciplinary recitation. At the recitation, all engineering and computer science students are placed into interdisciplinary teams where they work on a hands-on project that involves design and analysis, and they document and present their work with technical writing and oral presentations. The project incorporates multiple engineering and CS concepts, and emphasizes teamwork. The primary focus is on knowledge and comprehension of basic concepts within the context of a real-world application. The courses culminated in a design competition that includes a judged poster session and design demonstrations build by the interdisciplinary teams (see Figure 3).

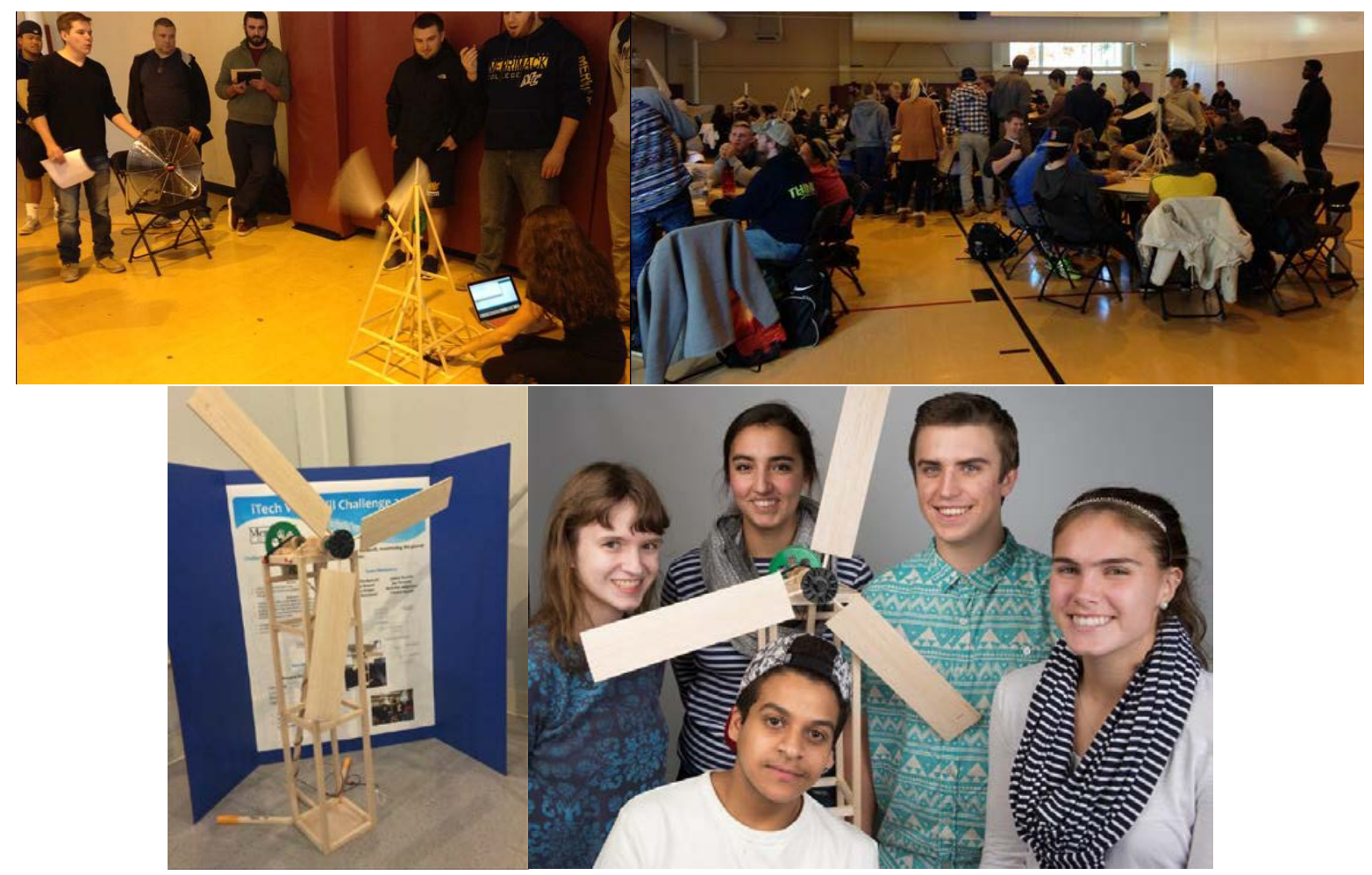

Figure 3 Photos of the 2015 gateway course design competition. The teams were required to design and build a wind turbine and were judged on the power output of their design. 


\section{Initiative \#3: Affinity Housing}

The affinity housing initiative is a living/learning community (LLC) of students majoring in engineering or CS. The affinity house has been dubbed the "iTEC LLC” for Innovations Through Engineering and Computing. The iTEC LLC is based on the Quadrangle Engineering and Sciences Living and Learning Community at the University of Colorado-Boulder. ${ }^{19}$ The iTEC LLC provides peer support outside the classroom, and directly address the need for social integration into the engineering and CS community. Student success and persistence in college has been shown to be tied to their social integration with peers and students are more likely to accomplish difficult tasks when engaged with individuals facing similar challenges. ${ }^{20}$

The iTEC LLC activities are intended for students living in the iTEC LLC but available and advertised to all engineering/CS freshman students and open to sophomore students as well. Activities consist of professional development sessions, nightly mentoring/tutoring in the iTEC LLC dormitory and community building activities. Specific activities have included a guest lecture by Henry Petroski (Professor at Duke University and author of numerous engineering and design related book including “To Engineer is Human”), tours of local construction sites and engineering/CS companies (iRobot, Raytheon, Haystack Observatory), and internship advice form upper classmen and recent alumni.

\section{Initiative \#4: Advising, Tutoring and Mentoring Program}

As part of FS2, the Advising, Tutoring, and Mentoring (ATM) program was designed and launched. Each year, the FS2 leadership team selects peer mentors (one for each cohort of 15 freshmen) from top performing, upper-division students in engineering and CS. The peer mentors reach out to their cohorts to meet several times a semester. These peer mentors help new students build their aspirations and academic confidence by welcoming and orienting them to the campus and its culture, and sharing with them their own academic/personal experiences and coping strategies.

Faculty and peer mentoring are best practices as recognized by the National Research Council, especially for first-generation students and groups underrepresented in STEM. ${ }^{12}$ The close personal relationship that develops between mentor and student can be one of the most important factors in determining the overall academic success of STEM students, and the quality of student/faculty interactions is key to student engagement and learning. ${ }^{13,14}$ Multiple studies underscore the importance of peer relations, in particular peer mentoring, during the undergraduate experience. 9, 15, 16, 17 The integration of academic and social support systems is especially important for students from groups underrepresented in science. ${ }^{18}$

A formal tutoring schedule (group and individual tutoring) for topics critical to first year students (i.e. mathematics, programming, physics and chemistry) is developed each semester. The peer mentors serve as tutors for the program and they are required to complete peer tutor training in accordance with tutoring standards for the College. To ensure a sustainable supply of tutors, the FS2 program encourages lower-division students to consider becoming peer tutors for the ATM 
program as they continue their studies. These future tutors will be able to use their experience as freshmen and sophomores to help the students who follow after them.

\section{Discussion of Preliminary Outcomes}

The FS2 project is currently in its second year and has engaged a total of 215 first year engineering and CS students as well as 20 upper division students as peer mentors. Table 1 shows the demographic breakdown of the two FS2 cohorts. The 2015/16 cohort is slightly larger however the demographics are very similar. Both cohorts are predominantly male, roughly a quarter of the cohorts are underrepresented in engineering, and nearly a third are $1^{\text {st }}$ generation college students.

Table 1 also shows the number and percentage of student within the 2014/15 cohort retained after one year. The retention rate for the male, female and $1^{\text {st }}$ generation students mimics the overall cohort rate of $76 \%$. Underrepresented students were retained at a slightly lower rate of $68 \%$. These retention rates are slightly higher or match the baseline retention rate of $67 \%$. The baseline first year retention was defined as the average retention for the combined civil, electrical and CS majors over a ten year period from 2002 to 2011. Mechanical engineering was not included in this baseline retention value because it is a new major and data was not available.

Table 1 FS2 Cohort Demographics and Preliminary Retention Data

\begin{tabular}{|c|c|c|c|c|c|}
\hline Cohort Year & $\begin{array}{c}\text { Cohort } \\
\text { Size }\end{array}$ & Male & Female & $\begin{array}{c}\text { Under- } \\
\text { represented }\end{array}$ & $\begin{array}{c}\text { 1st } \\
\text { Generation }\end{array}$ \\
\hline $2014 / 15$ & 101 & $88(87 \%)$ & $13(13 \%)$ & $22 \quad(22 \%)$ & $27(27 \%)$ \\
\hline \multirow{2}{*}{ Retained FA15 ==> } & 77 & 67 & 10 & 15 & 20 \\
\hline & $76 \%$ & $76 \%$ & $77 \%$ & $68 \%$ & $74 \%$ \\
\hline
\end{tabular}

\begin{tabular}{|l|l|ll|ll|ll|ll|}
\hline $2015 / 16$ & 114 & 93 & $(82 \%)$ & 21 & $(18 \%)$ & 32 & $(28 \%)$ & $35(31 \%)$ \\
\hline
\end{tabular}

Underrepresented students includes women, hispanic and african american students.

Table 2 indicates the number of students participating in the Summer Bridge, iTEC LLC and the Gateway initiatives and the percent participation in the cohort (shown in parenthesis). To date 86 students have participated in the iTEC LLC and 29 students have participated in the summer bridge program. Virtually all students in the cohorts participate in the gateway course. Participation in the iTEC LLC has increased from 31\% of the 2014/15 cohort to $48 \%$ of the 2015/16 cohort due to the implementation of an opt-out approach. Participation in the Summer Bridge remains below $15 \%$ for each cohort. This small size is intentional to ensure students receive direct faculty interaction. This effort seems to be worth-while as more than a quarter of the participants (29\%) placed into a higher math course after completing the two week intensive summer bridge program in 2015.

Table 2 also shows the retention rates by participation in these initiatives and indicates that Summer Bridge and iTEC LLC participants were retained at rates of 83\% and 87\%, respectively. 
This is noticeably higher than the overall cohort rate of $76 \%$ and more that $25 \%$ above the baseline retention of $67 \%$.

Table 2 Initiative Participation and Preliminary Retention Data

\begin{tabular}{|c|c|c|c|c|}
\hline Cohort Year & $\begin{array}{c}\text { Cohort } \\
\text { Size }\end{array}$ & $\begin{array}{c}\text { Summer } \\
\text { Bridge }\end{array}$ & $\begin{array}{c}\text { iTEC } \\
\text { LLC }\end{array}$ & Gateway \\
\hline $\mathbf{2 0 1 4} / \mathbf{1 5}$ & $\mathbf{1 0 1}$ & $\mathbf{1 2} \mathbf{( 1 2 \% )}$ & $\mathbf{3 1} \mathbf{( 3 1 \% )}$ & $\mathbf{1 0 0}(\mathbf{9 9 \% )}$ \\
\hline \multirow{2}{*}{ Retained FA15 ==> } & 77 & 10 & 27 & 76 \\
\cline { 2 - 5 } & $76 \%$ & $83 \%$ & $87 \%$ & $76 \%$ \\
\hline
\end{tabular}

\begin{tabular}{|l|l|l|l|l|l|}
\hline $2015 / 16$ & 114 & $16(14 \%)$ & $55(48 \%)$ & $110(96 \%)$ \\
\hline
\end{tabular}

Table 3 shows the performance of the 2014/15 cohort in their first year mathematics courses as measure by grades of D, F or Withdrawal. This table indicates the DFW rate of the total cohort, students who persisted to the sophomore year and students who did not persist to sophomore year in an engineering or CS major. $16 \%$ of students who persisted to Sophomore year earned a $\mathrm{D}, \mathrm{F}$ or $\mathrm{W}$ in a mathematics course their first year compared to $52 \%$ of students who left an engineering/CS major. Clearly performance in mathematics courses is an indication of whether students are likely to continue in an engineering/CS major.

Table 3 D,F, Withdrawal Rate in First Year Mathematics Courses of the 2014/15 Cohort

\begin{tabular}{|c|c|c|c|}
\hline & \# Course & \# DFW & Rate \\
\hline \multicolumn{4}{|l|}{ Total Cohort } \\
\hline 1st Semester $==>$ & 79 & 20 & $25 \%$ \\
\hline 2nd Semester $==>$ & 86 & 18 & $21 \%$ \\
\hline Total First Year $==>$ & 165 & 38 & $23 \%$ \\
\hline \multicolumn{4}{|c|}{ Persisting to Sophomore Year } \\
\hline 1st Semester $==>$ & 61 & 10 & $16 \%$ \\
\hline 2nd Semester ==> & 73 & 12 & $16 \%$ \\
\hline Total First Year $==>$ & 134 & 22 & $16 \%$ \\
\hline \multicolumn{4}{|c|}{ NOT Persisting to Sophomore Year } \\
\hline 1st Semester $==>$ & 18 & 10 & $56 \%$ \\
\hline 2nd Semester $==>$ & 13 & 6 & $46 \%$ \\
\hline Total First Year $==>$ & 31 & 16 & $52 \%$ \\
\hline
\end{tabular}

\section{Conclusions}

This paper describes the four initiatives of the Foundations for STEM Success project, the current status of the project as well as preliminary results. This is a 5 year project funded by NSF Grant \# DUE-1217285 and aims to increase the retention and graduation rates of engineering and computer science majors. Preliminary conclusions are listed below and are based on data from the first two years of the project. 
- Students who earn a D,F or W in a first year mathematics course are three times more likely to change out of an engineering or CS major.

- First year retention for students who participate in the Summer Bridge program and the iTEC LLC was $83 \%$ and $87 \%$, respectively. This is significant increase over the baseline retention of $67 \%$.

\section{Bibliography}

1. Barnett, E. A., Bork, R.H., Mayer, A.K., Pretlow, J., Wathington, H.D., and Weiss, M.J. (2012). "Bridging the gap: An impact study of eight developmental summer bridge programs in Texas". New York; National Center for Postsecondary Research, NCPR Brief. Retrieved November 23, 2012 from http://www.postsecondaryresearch.org/i/a/document/NCPR-BridgingtheGapBrief.pdf

2. Wischusen, S.M. and Winchusen, E.W. (2007). "Biology Intensive Orientation for Students (BIOS): A Biology "Boot Camp". ICBE Life Sciences Education. 6, 172-178.

3. Thayer, P. (2000). "Retention of students from first generation and low income backgrounds". Opportunity Outlook, the Journal of the Council for Opportunity in Education. May 2000, 3-9.

4. Kennedy, D. (2001). "Report on Academic Excellence". Council on Undergraduate Research Quarterly. September.

5. Koenig, K., Schen, M., Edward, M., and Bao, L. (2012). “Addressing STEM retention through a scientific thought and methods course”. Journal of College Science Teaching. 41(4), 23-29.

6. Minchella, D.J., Yazvac, C.W., Fodrea, R.A., and Ball, G. (2002). "Biology Resource Seminar: First Aid for the First Year”. The American Biology Teacher. 64(5), 352-357.

7. Friedman, D.B. and Alexander, J.S. (2007). "Investigating a first year seminar as an anchor course in learning communities”. Journal of the First-Year Experience \& Students in Transition. 19(1), 63-64.

8. Maisto, A.A. and Tammi, M.W. (1991). "The effect of a content-based freshman seminar on academic and social integration”. Journal of the Freshman Year Experience. 3(2), 29-47.

9. Miller, J.E., Groccia, J.E., and Miller, M.S. (2001). "Student-assisted teaching: A guide to faculty-student teamwork". Bolton, MA; Anker Publishing Company, Inc., xv-xix.

10. Lang, D.J. (2007). "The impact of a first-year experience course on the academic performance, persistence, and graduation rates of first-semester college students at a public research university". Journal of the First Year Experience and Students in Transition. 19(1), 9-25.

11. Sterba-Boatwright, B.D. (2000). "The effects of mandatory freshman learning communities: A statistical report”. Assessment Update. 12(2), 4-5.

12. NRC. (2011). "Expanding underrepresented minority participation: America's science and technology talent at the crossroads". National Research Council. Washington, DC. The National Academies Press.

13. Campbell, T.A. and Campbell, D.E. (1997). "Faculty/student mentor program: Effects on academic performanc and retention”. Research in Higher Education. 38, 727-742.

14. Umbach, P.D. and Wawrzynski, M.R. (2005). "Faculty do matter: The role of college faculty in student learning and engagement”. Research in Higher Education. 46(2), 153-184.

15. Swail, W.S., Redd, K., and Perna, L. (2003). "Retaining minority students in higher education: A framework for success". ASHE-ERIC Higher Education Report. 30(2).

16. Bordes, V. and Arredondo, P. (2005). "Mentoring and $1^{\text {st }}$-year Latina/o college students". Journal of Hispanic Higher Education. 10, 358-368.

17. Boud, D., Cohen, R., and Sampson, J. (2001). "Peer learning in higher education: Learning from and with each other”. London: Kogan Page Limited, 1-17.

18. Tinto, V. (1993). "Leaving college: Rethinking the causes and cures of student attrition”. (2 ${ }^{\text {nd }}$ ed.) Chicago: University of Chicago Press.

19. ASEE (2012). "Going the distance: Best practices and strategies for retaining engineering, engineering technology and computing students". American Society of Engineering Education.

20. Roberts, J.R. and Styron, R.Jr. (2010). "Student satisfaction and persistence: factors vital to student retention”. Research in Higher Education Journal. 6. 